\title{
Socio-Psychological Factors Affecting Participatory Planning Processes At Interactional Level
}

\author{
Katılımlı Planlama Süreçlerini Etkileyen \\ Etkileşim Düzeyindeki Sosyo-Psikolojik Faktörler
}

Neslihan KULÖZÜ,' İlhan TEKELi'²

\section{ABSTRACT}

Today, it is widely accepted that communities need to collaborate when making decisions on behalf of the individual, society and the environment. Hence, planners engaged in participatory initiatives need to understand how best to design and carry out a participatory planning process. In order to answer this question, all factors affecting participatory processes need to be determined, since only then can steps be taken to design and execute the best participatory process for each stakeholder in every unique context. By focusing particularly on the factors affecting participatory processes at interactional level, this study aims to determine the socio-psychological dimensions of participatory planning processes, the aim being to bring to light some hitherto unexplained factors involved and thus help to improve these processes. Based on previous discussions in participation literature, the ultimate aim of this study is to provide subsequent researchers and those involved in participatory planning practices with a framework on the socio-psychological dimensions, namely communication, power, attribution, relationships and persuasion, of participatory processes at interactional level.

\section{ÖZET}

Günümüz dünyasında bireylerin toplum ve çevrelerine ilişkin karar alma süreçlerine katılımlarının gerekliliği yaygın olarak kabul edilmektedir. Bu nedenle katılımlı pratiklerle uğraşan plancıların nasıl daha iyi katılımlı planlama süreçleri tasarlayıp sürdürebilecekleri sorusuna cevap bulmaları gerekmektedir. Bu soruya cevap bulmak için ise kathlımlı süreçleri etkileyen tüm faktörler belirlenmelidir, çünkü ancak katılımlı süreçlerin tüm boyutları anlaşıldığında her bir özgün bağlamda tüm paydaşlar için en iyi katılımlı sürecin tasarlanıp sürdürülmesine yönelik gerekli adımlar atılabilir. Katılımlı süreçleri etkileyen faktörlerden bireylerarası etkileşim düzeyindeki faktörlere odaklanan bu çalışmanın amacı katılımlı planlama süreçlerinin sosyo-psikolojik boyutlarını belirlemektir. Bu yolla katılımı süreçlerin keşfedilmemiş bir boyutu, katılımlı süreçleri geliştirmek niyetiyle eleştirel bir yaklaşımla ortaya koyulacaktır. Çalışmanın sonucunda gelecek araştırmalar ve katılımlı planlama pratikleri için katılımlı süreçlerin bireylerarası etkileşim düzeyindeki sosyo-psikolojik boyutları, iletişim, güç, atfetme, ilişkiler ve ikna etme olarak planlama literatürüne dayalı olarak ortaya koyulmaktadır.

'Department of City and Regional Planning, Ataturk University Faculty of Architecture and Design, Erzurum;

2Department of City and Regional Planning, METU, Faculty of Architecture, Ankara, Turkey.

'Atatürk Üniversitesi, Mimarlık ve Tasarım Fakültesi, Şehir ve Bölge Planlama Bölümü, Erzurum;

ODTÜ, Mimarlık Fakültesi, Şehir ve Bölge Planlama Bölümü, Ankara

Article arrival date: April 16, 2013 (Başvuru tarihi: 16 Nisan 2013) - Accepted for publication: February 21, 2014 (Kabul tarihi: 21 Şubat 2014 )

Correspondence (illetişim): Neslihan KULÖZÜ. e-mail (e-posta): nkulozu@atauni.edu.tr

๑ 2014 Yıldız Teknik Üniversitesi Mimarlık Fakültesi - @ 2014 Yıldız Technical University, Faculty of Architecture 
$\mathrm{n}$ parallel with the increasing tendency toward participatory practices in world, the concept of participation has also entered in the field of planning, which has thus become an interactive process having experienced a change in focus from plan and/or policy outputs to participatory processes. A participatory planning practice is a process of social influence, during which all of its main components are affected by the others, being the individual/group/society, the context and the process itself, all of which are bound together by a mutual social influence that has a transformative power over them. By focusing in particular on the factors affecting participatory processes related to individual/group/society, this study aims to determine the socio-psychological dimensions of participatory processes.

As one of the main components of participatory processes, it is necessary to define the individual/ group/society at individual, interactional and sociocultural levels, and it is the interactional level that is of particular interest to this study. By focusing on the interactional level, the unexplained factors related to individuals' interactions during the participatory process may be revealed. That has critical importance since today, it is widely accepted that communities need to collaborate when making decisions on behalf of the individual, society and the environment. For this reason, planners engaged in participatory processes need to understand how best to design and carry out a participatory planning process, and in order to find the answer to this question all factors affecting participatory processes need to be determined both for the further theoretical and empirical researches and participatory practices.

For this reason, this study reviewed the literature related to the subject with the intention being to explore the socio-psychological factors affecting the participatory processes. Within the context of this study, the literature review began with studies of titles that included the concept of 'socio-psychological factors/ dynamics/ dimensions' within participation, participatory planning and collective action literature (such as Adamson, 2010; Cooke, 2001; Burton, 2004; Denhardt et al. 2009; Dietz et al. 1998; Douglas 2006; Sood and Mitchell, 2004; Van Zomeren, 2009; Zappalà and Burrell, 2001). However, this review did not provide many concepts based on which socio-psychological factors could be categorized to determine socio-psychological dimensions of participatory processes. For this reason, the scope of the literature review is broadened to take in also literature related to other participatory practi- ces, including administrative science, conflict resolution, educational technology, architecture and economy (such as Franklin, 1975; Gayer et al. 2009; Hoffman and Bazerman, 2005; Hoffman and Henn, 2008; Hughes et al. 2002; Werner, 2008).

However, the literature review revealed very few studies related to the socio-psychological dynamics of participatory processes. Moreover, the studies that were identified raised different issues and had different dimensions under the title of socio-psychological dynamics/factors. For this reason, even many important issues at interactional level are pointed out by scholars within the context of participatory practice; none of the studies were able to provide a framework that would help define and discuss the socio-psychological dimensions of participatory processes. On the other hand, the review revealed that within a 10 -year period in participation literature, awareness had increased on the effects and importance of the sociopsychological dynamics of participatory processes; however the socio-psychological dimensions of participatory processes and their effects are yet to be addressed. For this reason, to determine the socio-psychological factors affecting the participatory processes at interactional level, the research was conducted within the participation literature. Through this way, for the use of theoreticians and practitioners in the field of planning and other fields focusing on the participatory experiences, the framework of socio-psychological dimensions of participatory processes will be provided which will help to reveal a part of invisible reasons behind the visible characteristics of participatory planning experiences.

Within the context of this study, only a limited number of articles have been searched, meaning that there may be other studies dealing with the socio-psychological attributes of participatory processes. However, given the limited scope of this research, being the systemization of socio-psychological dimensions, increasing the scope of the literature review is neither necessary nor possible. While there may be other socio-psychological dimensions of participatory processes that are not determined in this study, it is not the intention here to determine all such examples, but rather to what extent socio-psychological dimensions are discussed in the participation literature and related publications. As a secondary purpose, the paper categorizes the concepts that have been covered in literature to date, but not under the name of socio-psychological attributes/factors, as socio-psychological attributes, and in this way, to determine their socio-psychologi- 
cal dimensions. This study also aims to clear a path for later exploratory studies of other socio-psychological dimensions while investigating the effects on participatory processes of the socio-psychological dimensions determined in this study.

To this end, within the context of this study first, the participatory planning approach is discussed, mainly based on the Habermas' communicative rationality. Second, participatory planning processes are defined as a process of social influence among their main components, from which the relationship between participatory planning processes and the area of social psychology can be understood. Moreover, by determining the main components of participatory planning processes, this study focuses on the individual/group/ society as a main component of participatory processes. Third, for the purpose of this study, particular focus will be on the socio-psychological factors affecting participatory processes at interactional level, which will be further investigated with a review of previous literature, after which they will be categorized according to their common features with the knowledge of the literature on socio-psychological concepts. Finally, the socio-psychological dimensions of participatory processes at interactional level will be displayed.

\section{Participatory Planning Approach}

In the second half of the twenty century, under the effects of changes in procedural approaches, planning has started to be conceptualized as an interactive process, and the planning paradigm has changed in focus from plan and/or policy outputs to processes activated by social actors and their interactions within unique contexts. This transformation can be explained as a shift from rational-comprehensive planning to procedural planning. This paradigm change in planning has occurred in parallel to a shift from instrumental rationality to communicative rationality, and Habermas' work on the nature of communicative action is commonly accepted as having had a transformative impact on the planning field (Forester, 1989; Healey, 1997; Innes, 2004; Yiftachel and Huxley, 2000). Although not the only procedural planning approach, participatory planning approach based on Habermas' communicative rationality has come to dominate as a planning approach (Healey, 1992; 1997; 1999; Innes, 1995; 1996). Following in the wake of Habermas, who advocated the application of a collaborative model of decisionmaking as a tool to achieve the democratization of the wider society, many planners have developed their own approaches to planning, including collaborative planning (Brand and Gaffikin, 2007; Healey, 1997), communicative planning (Sager, 2001), deliberative planning (Forester, 1999) and consensus building (Innes, 2004) as more democratic planning processes. Even all of these planning styles are called by different names, in all planning is regarded as a communicative, interactive activity. In a similar way, this study focuses on participatory planning built on Habermas' communicative rationality.

Communicative planning theory first emerged with Forester's (1985) application of Habermas' theory of communicative rationality to planning, and Forester' works encouraged many other planning theorists (Healey, 1992; 1997; 1999; Innes, 1995; 1996; Innes and Booher, 1999; Sager, 1994) to pursue Habermasian theory as a basis for planning. Forester (1985) criticized rational-comprehensive planning built on instrumental rationality and its decision-making model, as within such a decision making process decisions were made using a scientific and technological framework, while rationality was constructed by the political and economic elites within society. Based on his criticisms, Forester (1985) went on to propose a new test of rationality for policy, plans and actions based on Habermas' communicative rationality. As stated by Healey (1997), the works of Forester formed a new basis of procedural theory in planning that accepted planning as an interactive process undertaken within a social context and this transition became known as the communicative turn in planning.

With communicative rationality, Habermas (1984) argues that in order to decide upon what action is to be taken in a particular situation; communities need to work collaboratively when assigning priority and validity to different claims. To explain the process, Habermas (1984) suggests the existence of an intersubjective consciousness, rejecting the concept that society is made up of atomistic individuals that interact as each attempts to maximize their own benefit (Forester, 1995; Healey, 1997). Habermas (1984) conceptualizes society as being made up of individuals whose consciousness is continually being socially constructed through their interactions with other individuals. According to Habermas (1984) individuals construct their conceptualization of reality in two ways. First, reality is constructed within an individual's own consciousness, based on their own perceptions, moral reasoning and emotive feelings; and second, the construction of reality by an individual is influenced through their interaction with other individuals as they construct their own realities. Habermas $(1984 ; 1990)$ argues that in such a context a decision-making model that encoura- 
ges the collective construction of goals can create an environment in which instead of the achievement of self benefit, achievement of collective understanding and agreement become the aim. With this decisionmaking model, which is the basis of the participatory planning approach, Habermas (1984) theorizes that interactions involving collective reasoning, discussion and analysis can result in a unified vision of reality, and asserts that with such a decision making process, the benefits will be wide-ranging and will result in an increase in the democratization of society and social capital.

In the present study, these two processes of conceptualization of reality defined by Habermas, which occurred during the participatory planning process, accept as the basis of the psychological and sociopsychological dimensions of participatory processes, which are affective on the participatory process; they shape participatory experiences and their achievements. However, since research at the individual level need to deeper psychological explanations, this study focuses on the socio-psychological factors affecting participatory processes at interactional level. As the focus of this study, the socio-psychological dimensions and their effects on the participatory process could only be understood by discussing on the participatory process.

\section{Participatory Planning Process and}

Its Main Components

Participatory planning is an interactive process activated by individuals and their interactions within a unique context. Different from the traditional planning approach, being focus of the participatory planning, process has carried special importance for the participatory planning approach, in that it addresses not only the substance of specific issues, but also how issues are discussed, how problems are defined and how strategies to address them are articulated. Although participatory planning involves some aspects of rational-comprehensive planning, including surveys, analyses, choices of strategy and monitoring (Healey, 1997), these activities are undertaken interactively within the participatory process. Moreover, different from a rational-comprehensive planning process, a participatory process does not set out to establish a set of procedures for activities to follow, as the aim instead is to help communities invent their own participatory processes; the result of which is inevitably a locally-specific process (Healey, 1997). Should the same project be conducted within different localities, the processes within each locality, and accordingly, the end-products of these contextually different processes, would be different. In short, every participatory planning process is as locally-specific and unique as the context in which the process is conducted.

However, this uniqueness of the participatory process comes not only from the different contexts in which it is conducted, as the different social actors and their interactions during the participatory planning process also play a part. Each participatory planning process involves different social actors, and even during individual participatory process, different social actors take part in different stages of the process depend on their wills, their roles in the participatory process and the process design of the participatory planning experience.

On the other hand, even each participatory process is unique, reaching consensus, through concessions or not, is the common aim of each participatory process. Consensus or inter-subjectively shared agreement as the successful conclusion of the participatory process is also one of the main assumptions and pre-conditions of participatory process based on Habermas' communicative rationality. However, even consensus building is an ideal for participatory practices, making concession in a peaceful environment is a way to reach consensus.

In addition to decisions or plans which are produced in the participatory process, as argued by Gruber (1994), a process in which consensus is built will produce mutual learning, social, intellectual and political capital. However, consensus is more than the mere arithmetic compromise that emerges if all involved stakeholders concede a little bit, but as it is stated by Innes (2004: 7) 'consensus is only reached when all interests have been explored and every effort has been made to satisfy these concerns'. Therefore, even there is optimism among scholars working on participatory practices about the force of a better argument and in turn the achievability of consensus, the participatory process and also consensus as a product of this process is affected by many factors such as those sociopsychological as focused on in the present study. To explore the factors affecting participatory process and so its achievements the main components of participatory processes should be clarified.

Attempts to define a participatory planning process and the factors that make it unique reveal three main components, being the individual/group/society, the context and the process itself, as conceptualized in Figure 1 . The first component of a participatory planning 
process is the process itself and its characteristics; second is the conducting of each process within a unique context, and third are the individual/group/society, some who are from the context in which the process is being realized and others who are not such as planners, process designers and experts. These three main components have their own particular components. For instance, the individual/group/society aspect, as the main focus of this study, has dynamics at individual, interactional and socio-cultural levels. While the individual level reveals a link between the participatory planning approach and the field of psychology, issues related to interactional and socio-cultural factors reveal a link particularly with the field of social psychology.

During the participatory process, interactions occur between the three main components, activating a parallel social influence process. Not only the process, but also the individual/group/society aspects and context are affected by the transformative effects of social influence (Figure 1). Therefore, the participatory planning process is described as a process of social influence that continues throughout the process as a constitutive element. On the other hand social influence is one of the main research areas of social psychology, and therefore to explore its nature during the participatory planning process, social influence may be discussed within the context of social psychology.

Social influence as a sub-area of social psychology aims to understand the nature and power of social influence and seeks to learn how individuals think or feel about, influence or interact with real or imagined others (Dunn, 2008). Individuals are connected with other individuals within society, with each individual being affected by all the others. As result of this social interaction between individuals and others, whether real or imagined, social influence is occurred. As stated by Dunn (2008) social influence is an elementary aspect of human societies and under the social influence of personal attitudes, the attitudes of groups and larger societies are formed. More specifically, different theoretical models emphasize different aspects of this experience.

Latané (1981) explains mutually social influence in his dynamic social impact theory, arguing that the real, implied or imagined presence or actions of others result in a variety of changes in physiological, emotional, motivational, cognitive and behavioral states through a dynamic and iterative influence process. This, in turn, constructs a social structure, producing localized cultures of beliefs. Another model is constructed upon the social influence network theory of Friedkin (1998), which, like the previous one, acknowledges social influence as a process, but further examines sociologically small group dynamics from both cognitive and structural perspectives. Friedkin argues further that networks of interpersonal influence contribute to the formation of interpersonal agreements and group consensus (Friedkin and Johnsen, 1999). Those involved revise their opinions as they engage with conflicting influential opinions, and the patterns and strengths of the interpersonal influences determine the influence network among the group members. Finally, Mosler and Brucks (2001) present both internal and external conditions in a model of social influence: the external being the influences coming from the outside, such as attitudes, persuasiveness, status, situational and incentives; and the internal

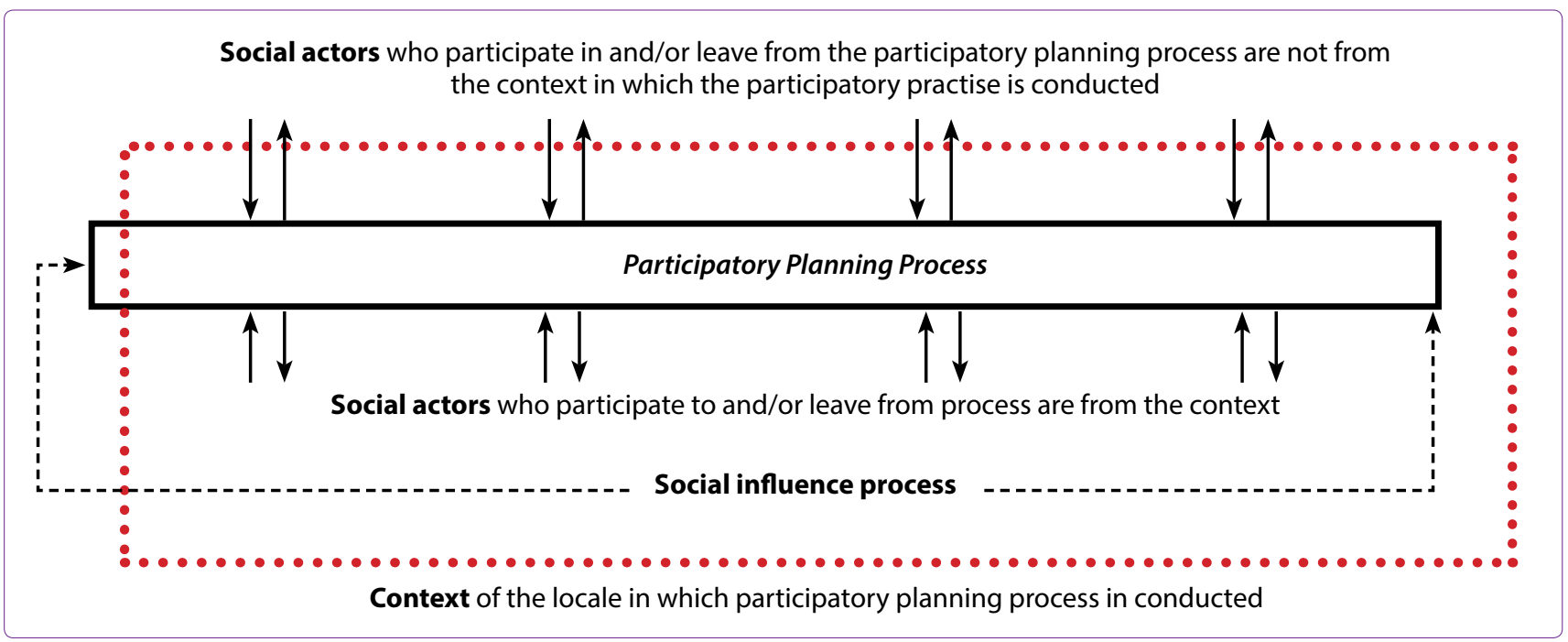

Figure 1. Participatory planning process and its main components. 
representing the effects from the inside, such as values, knowledge, self-responsibility and motives.

The subject has never before been addressed within planning literature based on this theoretical foundation; in which social influence can be considered as a constitutive element of the participatory planning process, affecting the participatory planning process by creating changes in an individual's thoughts, feelings, attitudes or behaviors, and in the interactions that bring about changes also within the socio-cultural context. In the course of a participatory process, social influence continues not only between individuals, groups and societies, but also in the transformative forces that exist between all of the three main elements of the process. For this reason, socio-psychological factors have become effective in participatory planning processes and are of paramount importance in planning field since they determine the participatory processes and their achievements.

\section{Socio-Psychological Factors Affecting}

\section{Participatory Processes}

As discussed previously, Habermas (1984) argues that the construction of reality is influenced by the individual's own perceptions, moral reasoning and emotive feelings and by interactions with other individuals. Participatory process is activated by interactions of individuals, through which individuals put into uses their knowledge and skills in the process. As a result of these interactions, social influence results in changes in the thoughts, feelings, attitudes and/or behaviors of the individuals, and these changes influence the participatory process and its achievements. Since during this interactive process, individuals may affect each other's way of construction of reality and they may construct their own reality which provides shifting from competing interests to consensus as the aim of the participatory process. During the participatory process individuals as the participants of process may work to reach consensus by communicating, by persuading each other's on their opinions, about the decision or plan which is the focus of the process, or by persuading each other to give concessions through using power over other participants. In short, during the participatory process, social actors may persuade the other social actors and change their opinions which are the way of building consensus. In this process, power, even if it is not a democratic way, may be used to reach consensus as it is argued by Foucauldian literature. As a result, depend on the individuals and their interactions within the unique context; consensus may be built with or without concession, or consensus may not be built during a participatory process. Therefore, the socio-psychological factors at interactional level that are resulted from interactions such as communication and power can be said to have transformative effects on the participatory process and its achievements.

As the two most discussed concepts in participatory approaches, communication and power are the sociopsychological dimensions at interactional level. While, communication is often discussed around the concept of Habermas' communicative rationality, discussions of power are based mainly on Foucauldian literature, which criticizes communicative theory and the communicative turn in planning. The central controversy between these two theoretical sides is their different conceptualization of power. According to Foucault's approach, power is a historically emerged phenomenon adjacent to the lifeworld itself that means power is not accepted as an 'outer distortion' to the lifeworld as it is accepted by Habermas and his followers (Mäntysalo, 2005). Foucauldian literature accepted power as a constructive force that shapes individuals' understandings and perceptions, as opposed to being seen as an outer distortion of individuals' communication. In a participatory process, the use of any kind of power changes the quality of consensus, which is defined as an ideal in Habermasian literature, turning consensus into concession, or consensus building with concession.

However, within the context of this study, instead of discussing on communication and power concepts around Habermasian and Foucauldian literatures, both communication and power and sub-issues related to them are determined as the socio-psychological factors at interactional level that are the main point of focus. In the field of social psychology, studies of the interactional level concentrate on theories and concepts in which people interpret one another's actions. It is the interactions that happen between people that are of interest, with the main focus being on the concept of communication. Communication is discussed as an interactional dimension that forms the basis of other socio-psychological dimensions. On the other hand, all of the socio-psychological dimensions are interrelated with each other.

After clarifying the context of socio-psychological factors at interactional level, this study continues with a review of literature related to the subject, with the intention being to determine the socio-psychological factors affecting the participatory processes. For this reason, the research was conducted within the participation literature. In this way, the socio-psychological factors and issues are gathered together and collected within the sub-groups depend on their commonalities, 
after which, these sub-groups were categorized based on the knowledge of social psychology, being communication, power, persuasion, attribution and interpersonal relationships (Table 1).

\section{Socio-Psychological Dimensions of the Participatory Processes at Interactional Level}

\section{Communication}

Communication, as generally defined, is the exchange of thoughts and information through speech, visuals, signals, writing or behavior. According to Terry (1997: 269), communication based on Habermas's studies, is 'a means to reach agreement through informed discourse in a revitalized sphere of public debate.' Communication is one of the basic socio-psychological dimensions of participatory processes since during a participatory process, social actors learn about each other and the process through communication, meaning that social actors get to know something about those with whom they communicate, as well as the subject of their communication when making decisions. Moreover, by communicating they try to persuade each other to reach consensus or persuade to give concessions in the cases where consensus could not be built without concessions.

Table 1. Socio-psychological factors ahd issues discussed within the participation literature

\section{Comunication}

Communication (Schulz et al. 2003; Shindler and Neburka 1997; Bickerstaff 2004)

Maintenance communication (Wandersman 2009)

Constructive dialogue (Dalton 2006; Webler et al. 2001)

Multi-way communication (Webler 1995)

\section{Power}

Manipulation (Dalton 2006), diverse control (Wandersman 2009)

Rewards and punishment (Hoffman and Henn 2008)

Power relations (Frewer 1999; Rowe et al. 2004)

Equal power (Webler et al. 2001; Schulz et al. 2003), equality (Crosby et al. 1986; Duffy 1991; Guynn and Landry 1997), power and equity (Bickerstaff 2004), power distance (Enserink et al. 2007)

Power orientation (Turner and Killian 1957)

\section{Persuasion}

Mobilization (Wandersman 2009)

Reward and punishment (Hoffman and Henn 2008)

Democracy in group (Frewer 1999; Rowe et al. 2004), a democratic management-unbiased (Cooper 2002)

Consensus-based interaction (Webler 1995)

\section{Attribution}

Consistency (Mahoney et al. 2003; Klein et al. 2001), change and consistency (Reis et al. 1993)

Commitment and clarity (Buchy and Hoverman 2000), the level of engagement and commitment of the partners (Dowling et al. 2004) Responsibility (Webler et al. 2001; Dowling et al. 2004), task and maintenance behaviors (Schulz et al. 2003; Webler et al. 2001), responsibility of participants (McCool and Guthrie 2001)

Critical self-reflection (Webler 1995)

Personal incentives (Wandersman 2009)

Fear of change, tradition of 'continuity', difficult changes in mentality (Pascani and Bujiu 2010)

\section{Relationships}

The care and feeding of participants (Shindler and Neburka 1997; Webler et al. 2001)

Entering the community (Hagmann et al. 1999)

Relationship building (McCool and Guthrie 2001)

Trust (Schulz et al. 2003; Bentrup 2001; Webler et al. 2001; Bickerstaff 2004), trust, reciprocity and respect between partners (Dowling et al. 2004), trust and confidence (Carnes et al. 1998; Tippett et al. 2005), mutual trust (Pascani and Bujiu 2010)

Hidden agenda (Cooper 2002) 
As the first socio-psychological dimension of participatory processes, communication is discussed alongside all of its different sub-issues within participation literature, in addition to Habermas' communicative rationality and communicative turn in planning. In the participation literature, Schulz et al. (2003), Shindler and Neburka (1997) and Bickerstaff (2004) talk about the concept of 'communication'; while Wandersman (2009) refers to 'maintenance communication'; Dalton (2006) and Webler et al. (2001) use the term 'constructive dialogue'; and Webler (1995) discusses 'multiway communication' (Table 1). These can be considered as the sub-concepts of the communication dimension discussed in participation literature. Looking these sub-concepts with the knowledge of the literature on socio-psychological concepts reveals continuity of communication as maintenance of communication, means of communication as multiway communication and type of communication as constructive dialogue as factors affecting the participatory processes.

\section{Power}

Power, using the well-known definition of Dahl (1957: 202), is defined as 'A has power over B to the extent that he can get $B$ to do something that $B$ would not otherwise do'. As the second socio-psychological dimension of participatory processes, power is discussed alongside its different sub-issues in both participation and Foucaldian literature. In addition, referring to power in terms of its influence on the participatory process, Dalton (2006) raises the concept of 'manipulation'; while Wandersman (2009) discusses 'diverse control'. Hoffman and Henn (2008) talks about 'reward and punishment', while Frewer (1999) and Rowe et al. (2004) discusses the concept of 'power relations'. Webler et al. (2001) and Schulz et al. (2003) mention 'equal power'; Crosby et al. (1986), Duffy, (1991) and Guynn and Landry (1997) use the concept of 'equality'; and Bickerstaff (2004) refers to power and equity; Enserink et al. (2007) use 'power distance'; and Turner and Killian (1957) refer to the concept of 'power orientation' (Table 1). These constitute the sub-concepts of the power dimension, as discussed in participation literature. Evaluating these sub-concepts with the knowledge of the literature on socio-psychological concepts raises power equality, power relations and different uses of power such as reward, punishment and manipulation as the factors affecting the participatory processes.

\section{Persuasion}

Persuasion is a deliberate attempt by one person to change the attitudes of others (Petty and Cacioppo,
1986). Although persuasion has not been the subject, it remains as one of the most important socio-psychological dimensions of participatory practices in that all participatory processes involve a persuasion process, at the end of which inter-subjectively established agreements, decisions or plans are produced. During participatory processes, social actors take a persuasive position so as to get their point across.

As the third socio-psychological dimension of participatory processes, persuasion is discussed alongside its different sub-issues in participation literature. As a factor affecting the participatory process, Wandersman (2009) discusses the concept of 'mobilization'; Hoffman and Henn (2008) addresses the concept of 'reward and punishment'; Frewer (1999) and Rowe et al. (2004) cite the concept of 'democracy in group'; Cooper (2002) mentions 'a democratic management'; and Webler (1995) refers to 'consensus-based interaction' (Table 1). These are the sub-concepts of the persuasion dimension discussed in participation literature. Looking these sub-concepts with the knowledge of the literature on socio-psychological concepts shows ways of persuasion as reward and punishment, consensus-based interaction and mobilization; and settings where persuasion is realized as democracy in a group as factors affecting the participatory processes within the context of the persuasion dimension.

\section{Attribution}

Attribution is a mental explanation that points to the cause of a person's behavior, and plays a role in the formation and evolution of interpersonal relationships (Kelley, 1973). Like persuasion, discussions of attribution in literature are not as common as those focusing on communication and power; however it constitutes another important socio-psychological dimension of participatory processes. Attribution dimension affects participatory processes by affecting the persuasion processes which resulted in consensus or not in relation with the attributes of power dimension.

As a socio-psychological dimension of participatory processes, attribution is discussed alongside different sub-issues within participation literature. While Mahoney et al. (2003) and Klein et al. (2001) refer to the concept of 'consistency'; and Reis et al. (1993) speak of the concept of 'change and consistency'; Buchy and Hoverman (2000) describe the concept of 'commitment and clarity' and Dowling et al. (2004) talk about 'the level of engagement and commitment of the partners'. Webler et al. (2001) and Dowling et al. (2004) mention the concept of 'responsibility'; Schulz et al. 
(2003) and Webler et al. (2001) refers to the concept of 'task and maintenance behaviors' and $\mathrm{McCool}$ and Guthrie (2001) use the concept of 'responsibility of participants'; Webler (1995) also speaks of the concept of 'critical self-reflection'; Wandersman (2009) discusses the concept of 'personal incentives'; and Pascaru and Buțiu (2010) refers to 'fear of change'. These are the sub-concepts of the attribution dimension, as discussed in participation literature. Looking these sub-concepts with the knowledge of the literature on socio-psychological concepts raises consistency and inconsistency, internal attribution such as critical self-reflection, personal incentives and fear of change, and external attribution such as responsibility, commitment and clarity as the factors affecting participatory processes.

\section{Interpersonal Relationships}

Relationship is a product of double-description, which enables us to begin to think of the two parties taking part in the interaction (Bateson, 1979). The interpersonal relationships dimension plays a role in the attempts of people to persuade others to effect changes in their attitudes during participatory processes.

As a socio-psychological dimension of the participatory processes, relationship is analyzed alongside its different sub-issues within participation literature. While Shindler and Neburka (1997) and Webler et al. (2001) refer to the concept of 'the care and feeding of participants'; Hagmann et al. (1999) discuss the concept of 'entering the community'; McCool and Guthrie (2001) speak of the concept of 'relationship building'; Cooper (2002) refers to the concept of 'hidden agenda'. Moreover, 'trust' as the most discussed socio-psychological dynamic of participatory processes is discussed by Schulz et al. (2003); Bentrup, (2001); Webler et al. (2001); Dowling et al. (2004); Carnes et al. (1998); Pascaru and Buțiu (2010), Bickerstaff (2004) and Tippett et al. (2005). Evaluating these sub-concepts with the knowledge of the literature on socio-psychological concepts reveals type of relationships as the care and feeding of participants, relationship building, hidden agenda and trust are revealed as factors affecting participatory processes.

\section{Discussion}

The present study focus on the factors affecting the participatory processes related to individuals' interaction to provide a framework for the further researches and participatory practices related to socio-psychological dimensions at interactional level with the intention being to improve the participatory processes.
As shown above, this issue has been documented to some degree in participation literature, but remains un-systematized, and does not provide a conceptual framework that can guide an understanding of what actually happens during such processes. This study clarified that communication, power, persuasion, attribution and interpersonal relationships are the sociopsychological dimensions of participatory processes at interactional level that is a part of unexplored factors affecting participatory processes.

Within the context of this study, communication has been determined as the first socio-psychological dimension of a participatory process. In addition to its importance as the basis of other socio-psychological dimensions, in participatory processes consensusbuilding requires effective communication between the participants of the process. The communication dimension, through its attributes, affects the process and its achievements, given that communication among the participants is a pre-condition of a participatory process, since communication start the process and its attributes provide for its continuity, after which consensus may or may not be achieved. As such an important dimension communication can be enhanced through various means, to be chosen depending on the contextual setting and needs in a particular participatory process. This calls for the planning of the communicative process with the stakeholders and the systematic implementation of the appropriate means. It is, however, essential that the application be flexible to take into account any unforeseen emergences.

Participation implies a redistribution of roles in the participatory planning process, enabling all participants to be deliberately included in the process, which is thus affected by the power of each participant. The power dimension, as the second socio-psychological dimension of participatory processes, and its attributes determine whether participation is an empty ritual, or whether all the participants have an element of influence in the planning process. The power dimension, through its attributes, determines the types of interactions and communications in a participatory process. Moreover, an increase in the use of power and power inequality in the process decreases the realization point of persuasion, leading to more concessions being made by participants with a low level of power. However, in a process dominated by asymmetrical relationships in the effects of power, consensus may be built, but such a process could not be determined as democratic. In contrast, in a process dominated by equal power relations and symmetrical relationships, 
consensus may be built democratically. On the other hand, 'power' remains as a permanent component of any social relationship, although different forms of power are evident in any interaction. Accordingly, it cannot be said that every power game can be identified and eliminated from participatory processes; although minimizing such situations through appropriate facilitation is practically possible by maintaining the objectivity of the facilitators, as the guarantors of the participatory processes.

Communication and power are the most commonly discussed concepts in participation literature based mainly on Habermasian and Foucaldian literature. However, the present study has not only focused on these two popular concepts and their attributes, but also determined other socio-psychological dimensions at interactional level and their attributes.

Attribution, focusing on how people draw inferences from one another's behavior during their interactions, is determined as the third socio-psychological dimension of participatory processes. The attribution dimension and its attributes are able to explain the behavior and tendencies of individuals and their changes in attitude during participatory processes. The attribution dimension, through its attributes, affects the functioning and quality of power, while also giving it shape and accordingly it affects also consensus building. Collective experiences like participatory planning processes contribute, to some degree, to the improvement of human capital, encouraging thinking and acting together. Accordingly, such initiatives should result in a gradual improvement of people's capacity to act in a more participatory and democratic way. On the other hand, although this may require experience and there may be a need for consciousness to evolve over time, it is possible to provide attribution in such a way that they ensure democratic communication. This necessitates fostering a mechanism of full participation, respecting diversity and eliminating distinctiveness.

So far, the interactional socio-psychological dimensions as communication and attribution have been discussed with reference to the concepts of participatory planning and consensus building, and power as the concept used to criticize participatory planning based on Habermas' theory. The relationships, as the fourth socio-psychological dimension, permits the discussion of other socio-psychological attributes at the interactional level, such as trust, as the most frequently discussed attribute in participation literature. The relationships dimension plays a role in attribution, persuasion, use of power and communication among individuals during the participatory processes, and is affected by other socio-psychological dimensions. The interpersonal relationships dimension, through its attributes, affects the participatory process and its achievements in terms of the level of attractiveness of participation within the relationships of the participants, the transparency of the process and the consistency of participants, fostering a sense of responsibility among the participants. Being such an important dimension, a great deal of effort and time should be given to, first, exploring relationships that enhance the participatory process, since this would reveal differences that depend on the context in which the process is conducted, and then activating such kinds of relationships. However, by giving the necessary time and effort required, which depends on the participants and the relationships among them, facilitators should approach and apply emphatically the appropriate tools for the engagement of participants into processes by building relationships, while also being aware of and respecting existing cultural and socio-psychological boundaries.

Although persuasion is determined in the present study as the last socio-psychological dimension at interactional level, to date it has not been discussed in participatory planning literature, despite its special significance for participatory processes. The building of consensus and the provision of continuity requires a process of persuasion among the participants, and for this reason, at the heart of any participatory processes, there should be a persuasion process that produces consensus with or without concession, and also affects the maintenance of consensus throughout the process. The persuasion dimension, through its attributes, affects participatory processes and their achievements, since it defines the end point of the process, with the type of persuasion being mostly affected by the power dimension and the power attributes in the participatory process. Since persuasion is, without doubt, a fundamental component of democratic dialogue, every attempt at participatory processes should include an appropriate setting in which the persuasion mechanism can operate. This can be done by reminding the participants on a regular basis, facilitating dialogue in an appropriate way, and applying dialogical tools that allow interactive and constructive communication. However, since the more persuasive characters in the group may easily dominate the direction of discussions, it is again up to the facilitators to maintain a balance between what is persuasive and what is dominating, and to moderate the process in the most democratic way. Other than that, the interventions should ideally encourage the participants to 
make a personal effort to contribute to the collective improvement of participation, without relying on any kind of power.

In conclusion, this study presents a framework of socio-psychological dimensions at interactional level and defines their attributes, that is especially important to understand how would help in the design and application of better participatory processes for all participants. Knowing the socio-psychological dimensions and their attributes, as a part of unexplored factors affecting participatory processes, clears a path for the exploration of their hindering or enhancing effects; and by considering these effects, socio-psychological attributes may be intervened during the participatory process. ${ }^{1}$

In terms of interventions, while some of the sociopsychological attributes at interactional level may be intervened within the context of a participatory process and in a short period of time, such as continuity of communication and means of communication, others cannot be subjected to intervention, or intervention may take too long, such as in the case of power relations or different usages of power. The determination of the socio-psychological attributes that may be intervened during the process and the means of intervention are of critical importance, since this also provides the frame in which required actions can take place before or during the participatory process. The determination of the areas in which actions can be initiated against the obstacles to the participatory processes would increase the chance of a more democratic and successful participatory experience for each stakeholder.

However, it should be considered that socio-psychological attributes and dimensions may affect each unique participatory process in different ways owing to the uniqueness of each participatory process and the context - while one attribute may enhance a participatory planning practice, it may hinder another. Therefore, during each participatory planning process, the socio-psychological attributes and their effects should be explored, and depending on the findings, necessary interventions should be set in motion to decrease the hindrances and enhance the beneficial effects.

\footnotetext{
In the present study the concept of intervention does not refer to an attempt to change and/or control every individual, interactions or stage of the participatory process. Rather, it is used to define necessary acts during the process and to design and moderate/facilitate the process by raising awareness of these dimensions/attributes. Since the aim of intervention is to increase the likelihood of the realization of the participatory processes, the intervention will help to reach consensus by democratic means by minimizing the hindering effects of the dimensions/attributes of participatory processes.
}

In summary by categorizing the discussed sociopsychological issues and concepts found in participation literature, this study has provided a framework for further studies on the socio-psychological dimensions of participatory processes, being communication, power, persuasion, attribution and relationships, and their attributes, for researchers, participatory planners and participatory process designers. Although the concepts of power and communication have been discussed within planning literature, the dimensions that have been determined as socio-psychological in the present study have not been discussed as sociopsychological dimensions of participatory processes, nor have their effects on participatory processes been explored or examined. For this reason, providing a framework of the socio-psychological dimensions of participatory processes is important for opening the way for an exploration and examination of their effects on participatory processes in different contexts, and may lead to an improvement in procedural planning approaches and participatory processes, since only when all aspects are understood can steps be taken to design and execute the best participatory process for each stakeholder in every unique context.

\section{References}

1. Adamson, D. (2010) Identifying the barriers to purposeful citizen participation. International Journal of Sociology and Social Policy 30, no. 3/4, 114-126.

2. Bentrup, G. (2001) Evaluation of a Collaborative Model: A Case Study Analysis of Watershed Planning in the Intermountain West. Environmental Management 27, no.5, 739-748.

3. Brand, R., and Gaffikin, F. (2007) Collaborative Planning in Uncollaborative World. Planning Theory 6, no.3, 282313.

4. Buchy, M., and Hoverman, S. (2000) Understanding Public Participation in Forest Planning: A Review. Forest Policy and Economics 1, 15-25.

5. Burton, R.J.F. (2004) Reconceptualising the 'behavioural approach' in agricultural studies: a socio-psychological perspective. Journal of Rural Studies 20, 359-371.

6. Carnes, S.A., Schweitzer. M., Peelle, E.B., Wolfe, A.K., and Munro, J.F. (1998) Measuring the success of public participation on environmental restoration and waste management activities in the U.S. Department of Energy. Technology in Society 20, 385-406.

7. Cooke, B. (2001) The Social Psychological Limits of Participation? In Participation: a New Tyranny? edited by B. Cooke, and U. Kothari, 102-121. Zed Books, London, Newyork.

8. Cooper, J. (2002) Evaluating Public Participation in the Environmental Assessment of Trade Negotiations. Report for Department of Foreign Affairs and International Trade, December. 
9. Crosby, N., Kelly, J.M., and Schaefer, P. (1986) Citizens Panels: A New Approach to Citizen Participation. Public Administration Review 46, no.2, 170-178.

10. Dahl, R. (1957) The concept of power. Behavioral Science 2(2), 201-215.

11. Dalton, T.M. (2006) Exploring Participants' Views of Participatory Coastal and Marine Resource Management Processes. Coastal Management 34, 351-367.

12. Denhardt, J., Terry, L., Delacruz, E.R., and Andonoska, L. (2009) Barriers to Citizen Engagement in Developing Countries, International Journal of Public Administration, 32 (14), 1268-1288.

13. Dietz, T., Stern, P.C., and Guagnano, G.A. (1998) Social Structural and Social Psychological Bases of Environmental Concern. Environment and Behaviour 30 (4), 450-471.

14. Douglas, A.B. (2006) Exploring the Barriers to Community Involvement in Public Transportation: The Case of Capital Metro. Public Administration Program Applied Research Projects. An Applied Research Project Submitted to the Department of Political Science Texas State University, Spring.

15. Dowling, B., Powell, M., and Glendinning, C. (2004) Conceptualising successful partnerships. Health and Social Care in the Community 12(4), 309-317.

16. Duffy, D.M. (1991) An Evaluation of Stakeholder Involvement in the B.C. Ministry of Forest Planning Process. MS thesis, The University of British Columbia, Canada.

17. Dunn, D.S. (2008) Research Methods for Social Psychology. Blackwell Publication, Malden, MA.

18. Forester, J. (1989) Planning in the Face of Power. University of California Press, Los Angeles, CA.

19. Forester, J. (1985) Designing: Making Sense Together in Practical Conversations. Journal of Architectural Education 38(3),14-20.

20. Forester, J. (1999). The Deliberative Practitioner: Encouraging Participatory Planning Processes. The MIT Press.

21. Franklin, J.L. (1975) Relations Among Four Social-Psychological Aspects of Organizations. Administrative Science Quarterly 20 (3), 422-433.

22. Frewer, L. (1999) Risk Perception, Social Trust, and Public Participation in Strategic Decision Making:Implications for Emerging Technologies. Ambio 28(6), 569-574.

23. Friedkin, N.E. and Johnsen, E.C. (1999) Social influence networks and opinion change. Advances in Group Processes 16, 1-29.

24. Friedkin, N.E. (1998) Structural Theory of Social Influence. Cambridge, UK: Cambridge University.

25. Gayer, C.C., Landman, S., Halperin, E., and Bar-Tal, D. (2009) Overcoming Psychological Barriers to Peaceful Conflict Resolution: The Role of Arguments about Losses. Journal of Conflict Resolution. 53 (6), 951-975.

26. Guynn, D.E., and Landry, M.K. (1997) A Case Study of Citizen Participation as a Success Model for Innovative Solutions for Natural Resource. Wildlife Society Bulletin 25(2), 392-398.

27. Habermas, J. (1984) The theory of communicative action vol.1 (trans. by Thomas McCarthy), Polity Press, Boston : Beacon Press ; Cambridge.
28. Habermas, J. (1990) Moral Consciousness and communicative action. MIT Press, Cambridge, Mass.

29. Hagmann, J., Chuma, E., Murwira, K., and Connolly, M. (1999) Putting Process into Practice: Operaionalising Participatory Extension in Agren. Network Paper no. 94.

30. Healey, P. (1992) Planning Through Debate: The Communicative Turn in Planning Theory. The Town Planning Review 63 (2),143-162.

31. Healey, P. (1997) Collaborative planning: shaping places in fragmented societies. Palgrave Macmillan,Basingstoke, Hampshire; New York.

32. Healey, P. (1999) Institutional analysis, communicative planning, and shaping places. Journal of Planning Education and Research 18(2), 111-121.

33. Hoffman, A., and Bazerman, M.H. (2005) Changing Environmental Practice: Understanding and Overcoming the Organizational and Psychological Barriers. Ross School of Business Working Paper Series Working Paper no. 923.

34. Hoffman, A. and Henn, R. (2008) Overcoming the Social and Psychological Barriers to Green Building, Ross School of Business Working Paper Series Working Paper no. 1106.

35. Hughes, S.C., Wickersham, L., Ryan-Jones, D.L., and Smith, S.A. (2002) Overcoming Social and Psychological Barriers to Effective On-line Collaboration. Educational Technology and Society 5(1), 86-92.

36. Innes, J.E. (1995) Planning theory's emergence paradigm: communicative action and interactive practice. Journal of Planning Education and Research 14(3), 183190.

37. Innes, J.E. (1996) Planning through Consensus building: A new view of the comprehensive planning ideal. Journal of American Planning Association 62 (4), 460-472.

38. Innes, J.E. (2004) Consensus Building: Clarifications for the Critics. Planning Theory 3 (1), 5-20.

39. Innes, J.E., and Booher, D.E. (1999) Consensus Building and Complex Adaptive Systems. Journal of the American Planning Association 65(4), 412 -423.

40. Kelley, H.H. (1973) The processes of Causal Attribution. American Psychologist 28(2), 107-128.

41. Klein, J.G., John, A., and Smith, N.C. (2001) Exploring Motivations for Participation in a Consumer Boycott, Centre for Marketing Working Paper no. 01-701.

42. Latane, B. (1981) Psychology of Social Impact. American Psychologicsts 36 (4), 343-356.

43. Mahoney, J.L., Cairns, B.D. and Farmer, T.W. (2003) Promoting Interpersonal Competence and Educational Success Through Extracurricular Activity Participation. Journal of Educational Psychology 95(2), 409-418.

44. McCool, S.F., and Guthrie, K. (2001) Mapping the Dimensions of Successful Public Participation in Messy Natural Resources Management Situations. Society and Natural Resources 14 (4), 309-323.

45. Mosler, H.J. and Brucks, W. (2001) Social Influence among Agents: The Simulation of Social Psychological Theories. Applications in the Social Sciences, 125-147.

46. Pascaru, M., and Buțiu, C.A. (2010) Psycho-Sociological Barriers to Citizen Participation in Local Governance: The 
Case of Some Rural Communities in Romania. Local Government Studies 36 (4), 493-509.

47. Petty, R.E. and Cacioppo, J.T. (1986) The Elaboration Likelihood model of persuasion. Advances in Experimental Social Psychology 19,123-205.

48. Reis, H.T., Lin, Y., Bennett, M.E. and Nezlek, J.B. (1993) Change and consistency in social participation during early adulthood. Developmental Psychology 29(4), 633645.

49. Rowe, G., Marsh, R., and Frewer, L. (2004) Evaluation of a Deliberative Conference. Science Technology Human Values 29, 88-121.

50.Sager, T. (2001) Positive theory of planning: the social choice approach. Environment and Planning A 33, 629647.

51. Sager, T. (1994) Communicative Planning Theory, Aldeshot Avebury.

52.Schulz, A.J., Israel, B.A., and Lantz, P. (2003) Instrument for evaluating dimensions of social dynamics within community-based participatory research partnerships. Evaluation and Program Planning 26, 249-262.

53. Shindler, B., and Neburka, J. (1997) Public Participation in Forest Planning: Attributes of Success. Journal of Forestry 95 (1), 17-19.

54.Sood, K.K., and Mitchell, C.P. (2004) Do Socio-psychological Factors Matter in Agroforestry Planning? Lessons from Smallholder Traditional Agroforestry Systems, Small-scale Forest Economics. Management and Policy 3(2), 239-255.

55. Tippett, J., Searle, B., Pahl-Wostl, C., and Rees, Y. (2005) Social learning in public participation in river basin management-early findings from HarmoniCOP European case studies. Environmental Science and Policy 8, 287299.

56. Turner, R.H., and Killian, L. M. (1957) Collective Behavior. Englewood Cliffs, N.J.: Prentice-Hall.
57. Wandersman, A. (2009) Four Keys to Success (Theory, Implementation, Evaluation, and Resource/System Support): High Hopes and Challenges in Participation, American Journal of Community Psychology. doi 10.1007/ s10464-008-9212-x. (accessed 30 January 2009).

58. Webler, T., Tuler, S., and Krueger, R. (2001) What is Good Public Participation Process? Five Perspectives from the Public. Environmental Management 27 (3), 435-450.

59. Webler, T. (1995) "Right" discourse in citizen participation: An evaluative yardstick. In Fairness and competence in citizen participation: Evaluating models for environmental discourse edited by O. Renn, T. Webler, and P. Wiedemann, 35-86. Kluwer, Dordrecht.

60. Werner, A. (2008) Using a Socio-psychological Approach for Understanding the Influence of Civil Society on Economic Activity. ZFWU 9/1, 153-168.

61. Van Zomeren, M. (2009) Introduction to the Social and Psychological Dynamics of Collective Action. Journal of Social Issues 65 (4), 645-660.

62. Yiftachel, O., and Huxley, M. (2000) Debating Dominance and Relevance: Notes on the Communicative Turn in Planning Theory. International Journal of Urban and Regional Research 24 (4), 907-913.

63.Zappalà, G. and Burrell, T. (2001) Why are some volunteers more committed than others? A socio-psychological approach to volunteer commitment in community services. Research and Social Policy Team Working Paper no.5.

Key words: Communicative rationality; interactional level; participatory planning approach; participatory process; socio-psychological factors.

Anahtar sözcükler: Iletişimsel rasyonalite; etkileşim düzeyi; katılımlı planlama yaklaşımı; katılımlı süreç; sosyo-psikolojik faktörler. 